\title{
GLL
}

○๐=

\section{MODIFIED MULTI-VALUED METHOD AS AN EFFECTIVE WAY OF IDENTIFYING INVESTMENT AREAS, AS ILLUSTRATED WITH THE EXAMPLE OF DOBCZYCE TOWN}

\author{
Urszula Litwin, Karolina Misiak
}

\begin{abstract}
Summary
The multi-valued method proposed by Walerian Wierzchowski [1996], subsequently modified by U. Litwin and K. Misiak, is a combination of cartographic research methods and mathematical analyses. The proposed technique presented in action can be viewed as a series of feasibility studies, which are the necessary foundation for programming the optimal structure of land use in urban areas.

As exemplified in the collected information, various cartographic studies and existing data about the town of Dobczyce, four possible designated functions have been presented, of which priority was given to the industrial function. The obtained results confirmed the effectiveness of the developed method, its usefulness in the planning practice, while highlighting the synergistic effects of the set objectives.
\end{abstract}

\section{Keywords}

multi-valued method • land planning • technical infrastructure $\bullet$ industrial function

\section{Introduction}

Dynamic development of urban and suburban areas, which is a consequence of the ever new and larger needs of the local communities as well as the changes taking place in spatial infrastructure and economy, enforces changes in the structure of land management. This applies both to changing the purpose and development of particular areas within the city, such as its centre, as well as to changes in areas that constitute the city's less urbanized surroundings, namely, its suburban zones. Today, the properly organized and planned rational space-functional arrangement, which maintains the correctness of technical, economic and aesthetic solutions, is becoming the essence of the proper functioning of this type of an urban-suburban unit.

Spatial planning is becoming the basic tool in the hands of local government authorities who exercise power in such units - and that is defined in local spatial development 
plans, which take account of standards, regulations and proposals for the development of a given area. These documents constitute a legal regulation of all changes currently taking place, and such that may take place in the future, while ensuring spatial order. Therefore, it is important to fully present the possibilities of developing particular spatial development functions. Proper spatial planning is based on rational management, taking into account all the natural, social, economic and cultural conditions (determinants) as well as the principles of spatial order, while protecting the natural environment and the local cultural heritage. This is aimed to ensure the proper development of the country, regions, counties (districts), municipalities (communes), and cities. Priority spatial planning tasks include sustainable use of the features and values of the area included in the local plan, in order to achieve the adopted development goals as well as conducting rationally placed development activities, coordinated in time and space of the entire plan, while maintaining synergy of these activities, and protecting the existing local assets.

One of the most fundamental problems of contemporary cities is to maintain the balance between economic growth and social development. The current state and level of spatial development of urban areas and the on-going socio-economic processes have had a significant impact on the living conditions - influencing not only of the people who live in these particular areas, but also impacting the economic development of the entire region, and sometimes even the whole country. A detailed analysis of the functional structure of these areas, along with an appropriate interpretation of the obtained results, is the key to determining the correct solutions allowing for the transition from the existing to the desired development, and thus to the proper spatial planning of specific areas [Stola 1993]. The aforementioned concept of spatial planning is defined by Pogodziński [1975] as a "set of institutions, methods and actions for the rational management of space". This issue also covers the location of investment projects, the control of the implementation of the developed and agreed concepts and plans, as well as the systematic, on-going assessments of the spatial development of particular areas covered by the planning activities.

One implication of the on-going changes in the urban space is the need to re-develop the areas that cannot or do not perform their assigned functions properly, or they ceased to perform their previous functions. These municipal functions are presented in the figure 1.

The above figure shows a diagram of functions that can be performed in specific areas, each of them having a significant impact on the development and harmony in cities and rural areas. One of these is the tourism function. According to Warszyńska and Jackowski [1979, p. 208] "spatial units in which tourism is the dominant form of economic activity are commonly referred to as units with a tourism function, similarly as in the case of industrialized and agricultural areas, we refer to industrial functions and agricultural functions".

Matczak [1989, p. 29] acknowledges that "the tourism function should be understood as the entire social and economic activity of the city, which is aimed at servicing tourists, and which the city performs within the system of the national economy." Kurek and Mika [2007, p. 40] express similar opinions, indicating that the tourism function should be understood as "any social and economic activity in the specific locality or 
region, directed to the service of tourists, which results in its ability to meet tourismspecific needs". One of the endogenous interpreted functions is the residential function, which testifies to adapting the given area to providing people with shelter in the form of a house or a flat, through various types of housing (single-family, multi-family, terraced development, etc.). The adaptation of a given area to performing the function in question is evidenced, for example, by the level of development of technical infrastructure, and the ability to satisfy the basic needs of its residents.

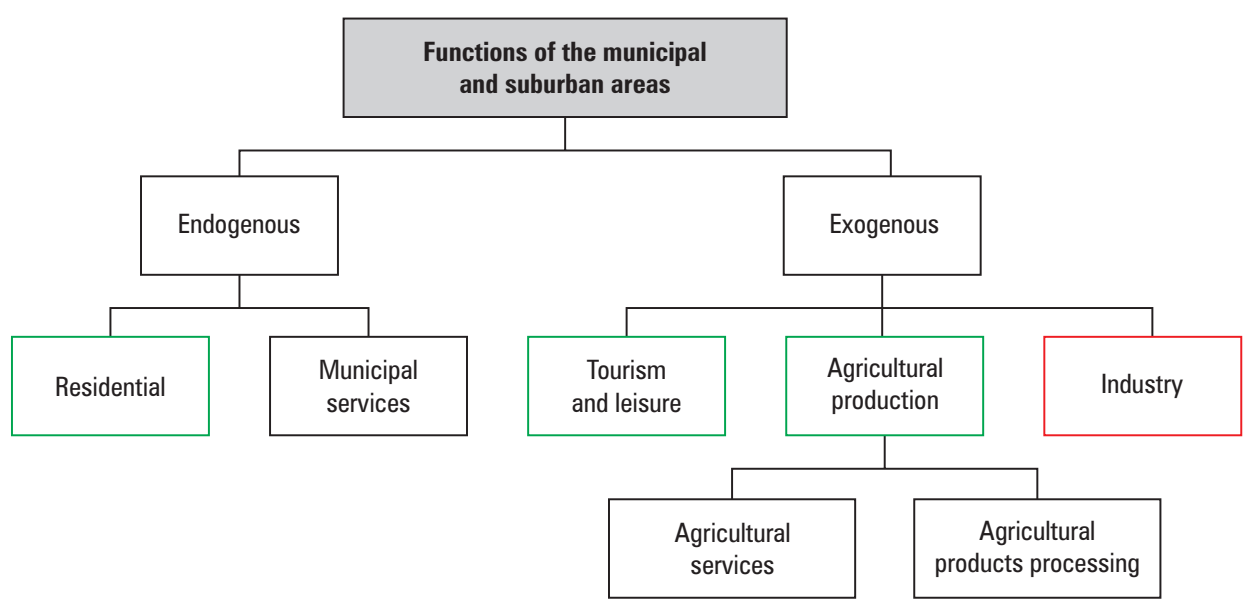

Source: own study based on Szczurowska et al. [2006]

Fig. 1. Diagram of the functions of the town and suburban areas - green colour denotes the functions included in the present study, as illustrated with the example of Dobczyce town

Similarly as in the case of the two other functions of cities that we mentioned, many social, economic and environmental factors determine the development of the agricultural function. All these features are linked by the land use structure, in which farmland plays the most significant role from the point of view of agricultural development.

In addition to the preliminary determination of the optimal function for the given area, the essence of all planning activities is to define the information resources that will facilitate the matching of a particular research method, appropriate for the purpose. As part of a broader interpretation, we shall briefly present the known methods of space valuation in this article.

The Point Bonitation Method consists in assigning individual features (of diversified value), occurring within the examined spatial unit, with the appropriate number of points determined according to the scale of values adopted in the study. In this way, various features that exist in a given environment are brought down to the common denominator, and the summation of the points assigned to them, regarding individual features, facilitates the possibility of a synthetic assessment of a given spatial unit from the point of view of the attractiveness of its environment [Lijewski et al. 2002]. 
The Bajerowski's Method of Value Matrix is a cartographic method, which involves a mathematical-statistical analysis of map foundations. It is based on an easy-to-use and universally available map content [Bajerowski 1991]. The method consists in collecting information from the grid of basic assessment fields, previously created in the analysed area. The aesthetic value of the interpreted landscape of each field follows from the numerical value assigned to it. The superimposition of the basic field grid on the map of the studied area makes it possible to construct an isarithmic map illustrating the intensity of the occurrence of a given phenomenon. It can be assumed that this value is inversely proportional to the degree of the deterioration of the studied landscape [Litwin et al. 2009].

The WIT Litwin Method is an expert method. The WTI index (area significance index) has been defined here for three basic functions: agricultural, non-agricultural and recreational. The index is an estimate of the "value" of each of the designated areas (villages) and types of activities, taking into account the adopted set of characteristics. The WIT indicator is calculated from the following formula:

$$
W I T=a_{1} z_{1} x_{1}+a_{2} z_{2} x_{2}+\ldots+a_{n} z_{n} x_{n}
$$

where:

$x_{1} \ldots x_{n}$ - denotes particular assessment criteria,

$a_{1} \ldots a_{n}$ - denotes weights assigned to particular criteria of $x$,

$z_{1} \ldots z_{n}$ - denotes coefficients of statistical significance for the particular criteria.

Each feature has been assigned a weight, determining its impact on the usability of the area for individual economic functions, and a coefficient defining the statistical significance of a given feature in relation to other features [Litwin 2004]. The "desirability" of a given characteristic is the positive or negative impact of the feature on the suitability of the area in question for a particular type of activity. The "significance" of a given feature, on the other hand, is the importance of that characteristic to a given activity in the studied area in terms of its potential. In order to determine the weights of "desirability", the expert test was used [Litwin 1997], in which thirty experts in various fields - including spatial development, environmental protection, and agriculture completed surveys listing all features, and assessed them in the appropriate point-based scale.

The Integrated Assessment of the Landscape Structure is based on the combination of landscape indicators used by other authors of the methods for evaluating space. Among others, this integrated method proposes an assessment model based on a set of various criteria: utility, economic, information, aesthetic, emotional and symbolic. By this, the method follows the premise that landscape assessment should take into account not only functional values or measurable indicators of the quality of living space, but that it should also consider intangible values as well as aesthetic and emotional experiences (admiration, delight) and didactic or educational values (the ability to read a story written in traces and symbols) [Raszeja and Mikulski 2016]. 


\section{The objective and scope of this elaboration}

The main goal of this paper is to present the effectiveness of the modified multi-valued method in defining the space that can become an area of detailed planning activity, which will serve to highlight those areas that are suitable for fulfilling the functions determined in the study, while paying particular attention to the location of investment areas. Analysis of the existing condition will help in determining the optimal use of land, by applying the cartographic method in the study, while maintaining appropriate guidelines.

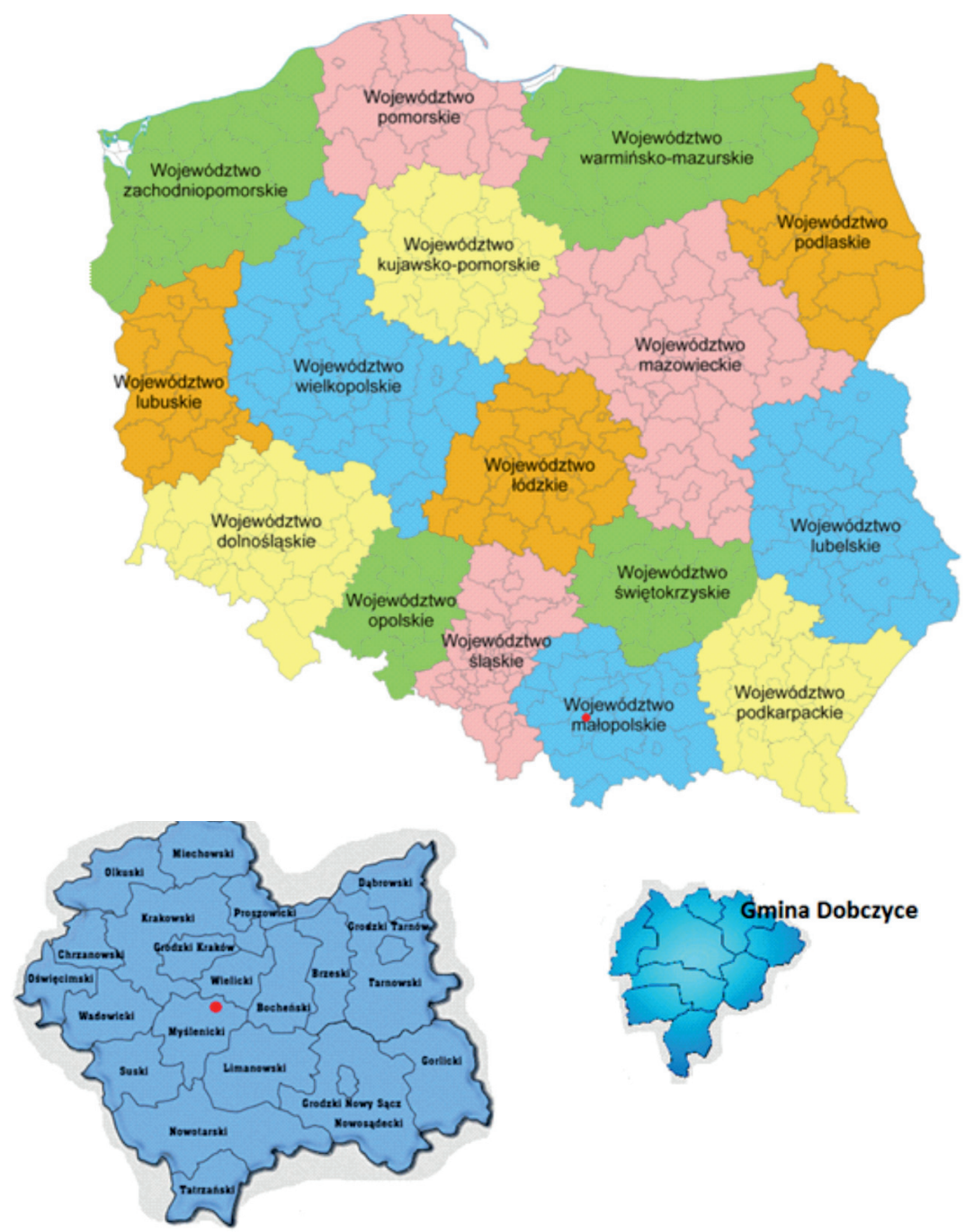

Source: Authors' study

Fig. 2. Location of Dobczyce town within the map of Poland (Dobczyce town is marked in red) 
The modified method makes it possible to indicate areas capable of performing not only one spatial function, but also those that are suited to perform two or more functions simultaneously. The adopted method exposes the so-called conflict areas. The method we applied enables quick and unambiguous definition of the space that can become an area of detailed planning activity, which will help optimize the use of these areas.

The scope of the study covers the area included within the administrative boundaries of the town of Dobczyce, the seat of the mixed urban-rural municipality. Dobczyce is located in the Małopolska region, in the Myślenice district. The urban area is located in the Raba river valley. The town of Dobczyce is located $30 \mathrm{~km}$ to the southeast of Kraków. According to statistical data from 2011, the town's total area is $12.97 \mathrm{~km}^{2}$, while the population density is 498.8 people $/ \mathrm{km}^{2}$.

In the research conducted in the city of Dobczyce, those areas that could be designed simultaneously for performing two or all three spatial functions listed below were considered conflict areas:

1. The function of handling tourism and leisure;

2. The function of single- and multi-family housing development;

3. The function of the agricultural production space;

4. Industrial function.

The most conflicting areas require the elaboration of a local spatial development plan or other detailed studies, as a priority.

\section{Research methodology applying the modified multi-valued method}

The modified multi-valued method used in the analysis allows for an objective and discretionary selection of areas requiring the development of local plans. When applied precisely and accurately, it is a source of information about the given area that requires undertaking of planning activities.

The process of identifying conflict areas by means of a multi-valued method consists of several stages. First of all, the type and scale of the map are determined, and the analysed area is divided into measurement sectors. Subsequently, we need to determine the designated functions of the area, and choose the set of conditions (determinants) for its evaluation, select the characteristic features for the assessment of the area, then quantify those features and determine the matrix of values for the features, and the matrix of values for the weights. Next, measuring sectors are selected that meet the adopted values of the designated functions, and finally a comprehensive evaluation of the studied area is carried out (leading to the selection of areas requiring local plans).

At the beginning, the type and scale of the map was determined, and the analysed area was divided into measurement sectors. The base map in the scale of $1: 1000$ was used as the main source of information about the studied object. This study contains an adequate amount of information on the status of the existing analysed space. The whole area within the boundaries of the study was divided into measurement sectors, each in the shape of a square with a side of $250 \mathrm{~m}$. The "measuring units" thus selected 
form a regularly arranged and numbered network (grid) from 1 to $\mathrm{n}$. As a result, 250 such measurement sectors were obtained (Fig. 3).

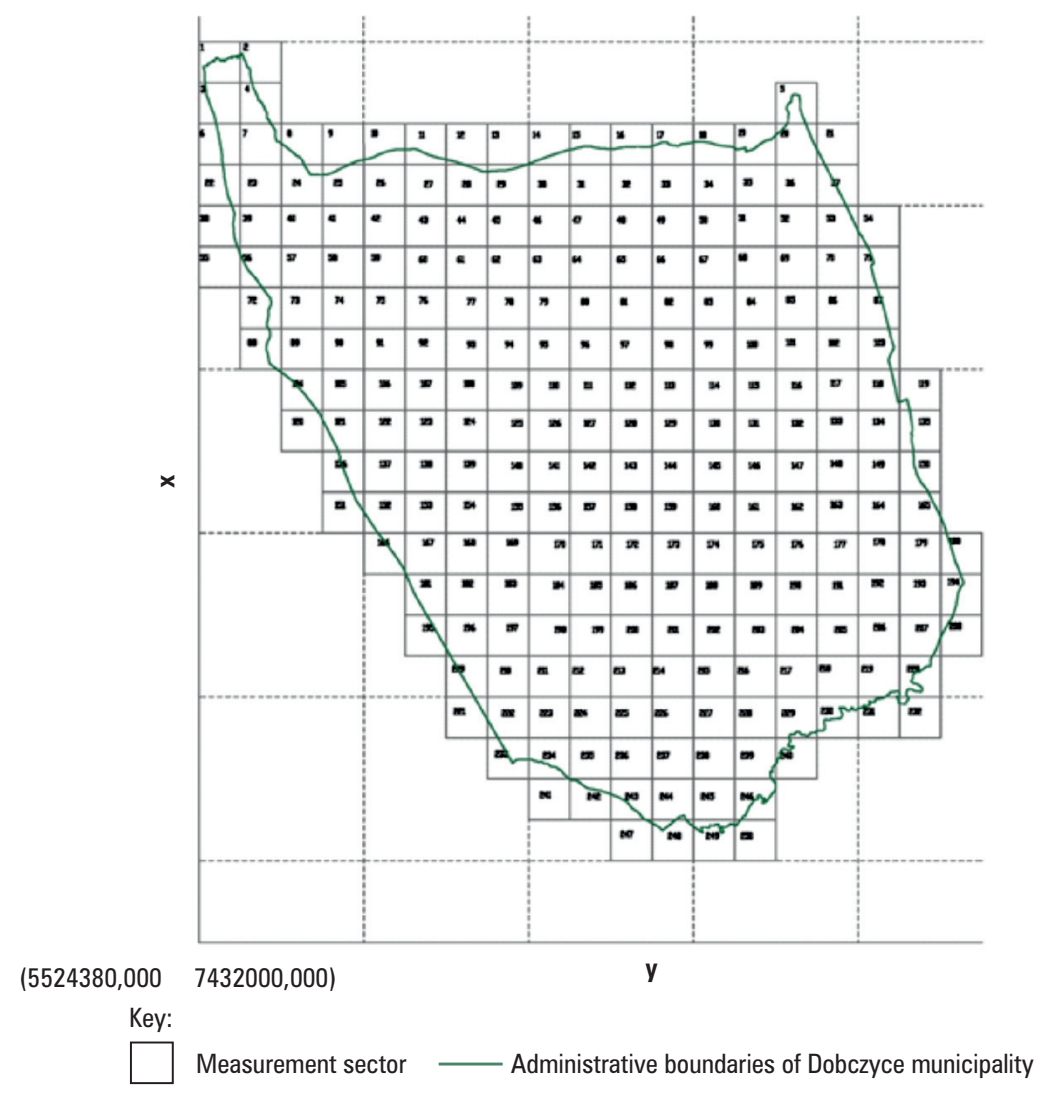

Source: Authors'study

Fig. 3. Measurement sectors within the area of Dobczyce town (cartographic map base)

In the next step, the analysis of the aforementioned maps and the current "Local Spatial Development Plan for the town of Dobczyce" was carried out, then, four basic objectives were selected, which were considered the main sources of the area's development drive. The sectors indicated at the last stage would constitute an effective planning activity and would support the further dynamic economic growth of the town. The following designated functions have been selected:

- The function of services for tourism and leisure;

- The function of one-family and multi-family housing development;

- The function of the agricultural production space;

- Industrial function. 
It should be noted that the method used in this study also allows for distinguishing other purposes and functional designations. Within a sector with a specific primary functional designation, areas with similar or associated primary use may occur, or areas with additional uses, as a result of synchronization of various existing land development elements with new assumptions and proposals that are not related with the basic designation and do not come into conflict therewith.

Each of the analysed sectors has received an assessment of fitness for the purpose of its functional designation. The values of the scores were determined, taking into account a variety of conditions. It is possible to adopt any number of the latter, however, based on the analysis of the studied area in terms of physical-geographical and socialeconomic aspects, we selected those conditions, which seemed to be the most important in the assessment of the city area for the purpose of local planning.

Environmental, economic, social, legal and aesthetic conditions (determinants) were chosen for the town of Dobczyce.

Next, the selection of appropriate features and their quantification will be used in order to determine the multi-valued assessment of the studied area. When determining the characteristic features that would describe each of the 250 sectors, one should be guided by certain conditions and principles:

- The diagnostic features must be characteristic due to the specific purpose of the conducted study;

- The diagnostic features represented should be generally accepted, systematized and variable in time;

- The diagnostic features must be poorly correlated with each other, but strongly correlated with other features that are not considered diagnostic;

- The diagnostic features should exhibit high spatial variability.

The aim of the features' selection is to disclose the most important elements and factors of a given space, which will significantly affect specific conditions. All the measurement sectors are considered as individual elements in Cartesian coordinate system, defined by a certain number of features, and disclosing the capability of a given sector to fulfil a previously determined designation.

The aforementioned representation of elements will be of both surface, linear and point character. The modified multi-valued method facilitates calculations of selected features at any time to be again verified - in order to supplement, correct or narrow them down. Taking into account all specific, predetermined conditions, and guided by the nature of the analysed area, fourteen features were selected (Table 1).

Each feature has a rating scale with three degrees of freedom: 0, 0.5, and 1, respectively. The use of such a number of features and conditions indicates the so-called interactive variant.

The next stage of the analysis was the creation of the $\mathrm{W}$-weight matrix, whose individual components are:

- rows - corresponding to fourteen characteristics (features),

- columns - corresponding to the functional designations,

- selected conditions (determinants) recorded in the individual layers of the matrix. 
All of the above components of the matrix $\mathrm{W}$ are represented using real numbers. Each of these elements corresponds to the size of the relevant characteristic feature for the specific functional designation of the area with a given conditioning. The appropriately and correctly chosen degree of freedom for each interpreted feature of a given sector plays a very important role. The values of the weights of the relevant conditions are meant to ensure, in the next stage of the analysis, the correct overall scores for each sector, and their mutual comparability.

Due to the fact that the rational use of space from the natural (environmental) and economic point of view takes place when the natural disposition of the area is used to a maximum extent for certain forms of land use functions, while minimizing its degradation, 14 features were selected with the aim of revealing the most important elements and factors of the examined space, having the greatest impact on the five considered conditions with a minimum weight of $1 / 16$ (Tables 1 and 2). These elements have both surface, linear and point character, and the measuring sectors are considered as elements in the Cartesian coordinate system.

Table 1. Weights of 14 features selected for particular conditions (determinants), for specific functions of land designation

\begin{tabular}{|c|l|r|r|r|r|r|}
\hline \multirow{2}{*}{ No. Feature } & \multirow{2}{*}{} & \multicolumn{5}{c|}{ Conditions } \\
\cline { 3 - 8 } & & ww1 & ww2 & ww3 & ww4 & ww5 \\
\hline 1 & Terrain forms & 17 & 0 & 0 & 0 & 0 \\
\hline 2 & Geological structure & 17 & 0 & 0 & 0 & 0 \\
\hline 3 & Type and usability of soils & 17 & 0 & 0 & 0 & 0 \\
\hline 4 & Forests and vegetation & 17 & 19 & 0 & 0 & 0 \\
\hline 5 & Water & 17 & 0 & 0 & 0 & 0 \\
\hline 6 & Land use structure & 0 & 19 & 0 & 2 & 0 \\
\hline 7 & Property structure & 0 & 19 & 0 & 0 & 0 \\
\hline 8 & Degree of land development and investment & 0 & 19 & 29 & 0 & 10 \\
\hline 9 & Aspirations and expectations of the local community & 0 & 0 & 31 & 0 & 0 \\
\hline 10 & Condition and value of the natural environment & 5 & 0 & 28 & 0 & 10 \\
\hline 11 & Spatial planning norms and regulations & 0 & 10 & 0 & 48 & 0 \\
\hline 12 & Applicable legal norms and regulations & 0 & 10 & 0 & 48 & 0 \\
\hline 13 & Natural and cultural attractiveness & 5 & 2 & 6 & 1 & 40 \\
\hline 14 & Spatial functionality and harmony & 5 & 2 & 6 & 1 & 40 \\
\hline
\end{tabular}

Source: Authors' study 
According the assumptions that underlie the method, all elements of the matrix take values in the range of -100 to 100 , and their sum total - for a given feature, for a given functional designation, and with the given conditions - equals 100. This statement can be presented in the following form:

where:

$$
\sum_{i=1}^{n} W_{i, j, k}=100
$$

$i$ - number of the feature,

$j$ - number of its designated function,

$k$ - number of the set of conditions.

The verification of the above condition for the $W$ matrix used in the analysis is as follows:

- $\quad$ ww1 $17+17+17+17+17+5+5+5=100$

- ww2 $19+19+19+19+10+10+2+2=100$

- $\quad$ ww3 $29+31+28+6+6=100$

- $\quad$ ww4 $2+48+48+1+1=100$

- ww5 $10+10+40+40=100$

Some of the features have scales that are different from zero for more than one condition. Therefore, they have an impact on the assessment of other conditions. The weights of these conditions do not depend on the number of features.

The VT area value matrix is a table in which rows are assigned to particular sectors, and columns are assigned to the features of the area. Elements of this matrix represent an assessment of the features of the area, its usefulness for the development of a given functional designation, within the area of the relevant sector.

For each of the three distinguished functional designations, matrices VT1 (Table 2), VT2 (Table 3), and VT3 (Table 4) were created accordingly.

Table 2. Fragment of the matrix of values assigned to features in the VT1 area for the first 10 measurement sectors

\begin{tabular}{|c|c|c|c|c|c|c|c|c|c|c|c|c|c|c|}
\hline \multicolumn{10}{|c|}{ Characteristic features of the area } & \multirow{2}{*}{$\begin{array}{c}\text { Sector } \\
\text { No. }\end{array}$} \\
\hline T1 & T2 & T3 & T4 & T5 & T6 & T7 & T8 & T9 & T10 & T11 & T12 & T13 & T14 & \\
\hline 0.5 & 0.5 & 0.5 & 1 & 0.5 & 0.5 & 0 & 0 & 0 & 0.5 & 0 & 0 & 0.5 & 0.5 & 1 \\
\hline 0.5 & 0.5 & 0.5 & 1 & 0.5 & 0.5 & 0 & 0 & 0 & 0.5 & 0 & 0 & 0.5 & 0.5 & 2 \\
\hline 0.5 & 0.5 & 0.5 & 0.5 & 0 & 0 & 0 & 0 & 0 & 0.5 & 0 & 0 & 0.5 & 0 & 3 \\
\hline 0.5 & 0.5 & 0.5 & 1 & 0.5 & 0.5 & 0 & 0.5 & 0 & 0.5 & 0.5 & 0 & 1 & 0.5 & 4 \\
\hline 0 & 0.5 & 0.5 & 0 & 0 & 0 & 0 & 0.5 & 0 & 0.5 & 0 & 0 & 0.5 & 0.5 & 5 \\
\hline
\end{tabular}




\begin{tabular}{|c|c|c|c|c|c|c|c|c|c|c|c|c|c|c|}
\hline 0.5 & 0.5 & 0.5 & 0.5 & 0 & 0 & 0 & 0 & 0 & 0.5 & 0 & 0.5 & 0.5 & 0 & 6 \\
\hline 0.5 & 0.5 & 0.5 & 1 & 0 & 0.5 & 0 & 0.5 & 0 & 1 & 0.5 & 0 & 1 & 1 & 7 \\
\hline 0.5 & 0.5 & 0.5 & 0 & 0 & 0 & 0 & 0.5 & 0 & 0.5 & 0 & 0 & 0 & 0.5 & 8 \\
\hline 0 & 0.5 & 0.5 & 0 & 0 & 0 & 0 & 0 & 0 & 0 & 0 & 0 & 0 & 0 & 9 \\
\hline 0.5 & 0.5 & 0.5 & 0 & 0 & 0.5 & 0 & 0.5 & 0.5 & 0.5 & 0.5 & 0 & 0 & 0.5 & 10 \\
\hline
\end{tabular}

Source: Authors' study.

Table 3. Fragment of the matrix of values assigned to features in the VT2 area for the first 10 measurement sectors

\begin{tabular}{|c|c|c|c|c|c|c|c|c|c|c|c|c|c|c|}
\hline \multicolumn{10}{|c|}{ Characteristic features of the area } & \multirow{2}{*}{$\begin{array}{c}\text { Sector } \\
\text { No. }\end{array}$} \\
\hline T1 & T2 & T3 & T4 & T5 & T6 & T7 & T8 & T9 & T10 & T11 & T12 & T13 & T14 & ( \\
\hline 0.5 & 0.5 & 0.5 & 1 & 0.5 & 0 & 0 & 0 & 0 & 0.5 & 0 & 0 & 0.5 & 0 & 1 \\
\hline 0.5 & 0.5 & 0.5 & 0.5 & 0.5 & 0 & 0 & 0 & 0 & 0.5 & 0 & 0 & 0.5 & 0 & 2 \\
\hline 0.5 & 0.5 & 0.5 & 1 & 1 & 0.5 & 0 & 0.5 & 0 & 0.5 & 0.5 & 0.5 & 0.5 & 0.5 & 3 \\
\hline 0.5 & 0.5 & 0.5 & 0 & 0.5 & 0 & 0 & 0.5 & 0 & 0.5 & 0.5 & 0.5 & 0.5 & 0.5 & 4 \\
\hline 0.5 & 0.5 & 0.5 & 0.5 & 1 & 0.5 & 0 & 1 & 0.5 & 0.5 & 0.5 & 0.5 & 0.5 & 0.5 & 5 \\
\hline 1 & 0.5 & 0.5 & 0.5 & 1 & 0.5 & 0 & 0.5 & 0 & 0.5 & 0.5 & 0.5 & 0.5 & 0.5 & 6 \\
\hline 1 & 0.5 & 0.5 & 0.5 & 0.5 & 0 & 0 & 1 & 0 & 0.5 & 0.5 & 0.5 & 0 & 0.5 & 7 \\
\hline 1 & 0.5 & 0.5 & 0 & 1 & 0 & 0 & 1 & 0 & 0.5 & 0 & 0 & 0 & 0.5 & 8 \\
\hline 0.5 & 0.5 & 0.5 & 1 & 1 & 1 & 0 & 1 & 0.5 & 0 & 1 & 1 & 0 & 0.5 & 9 \\
\hline 1 & 0.5 & 0.5 & 1 & 1 & 0.5 & 0 & 1 & 0.5 & 0.5 & 1 & 1 & 1 & 1 & 10 \\
\hline
\end{tabular}

Source: Authors' study

Table 4. Fragment of the matrix of values assigned to features in the VT3 area for the first 10 measurement sectors

\begin{tabular}{|c|c|c|c|c|c|c|c|c|c|c|c|c|c|c|}
\hline \multicolumn{10}{|c|}{ Characteristic features of the area } & \multirow{2}{*}{$\begin{array}{c}\text { Sector } \\
\text { No. }\end{array}$} \\
\hline T1 & T2 & T3 & T4 & T5 & T6 & T7 & T8 & T9 & T10 & T11 & T12 & T13 & T14 & \\
\hline 1 & 0.5 & 0.5 & 1 & 1 & 1 & 0 & 0.5 & 1 & 0.5 & 1 & 1 & 0 & 0.5 & 1 \\
\hline 1 & 0.5 & 0.5 & 0 & 1 & 0.5 & 0 & 0.5 & 1 & 0.5 & 0.5 & 0.5 & 0 & 0.5 & 2 \\
\hline 1 & 0.5 & 0.5 & 1 & 0.5 & 1 & 0 & 1 & 1 & 0.5 & 1 & 1 & 0 & 0.5 & 3 \\
\hline 1 & 0.5 & 0.5 & 0 & 1 & 0.5 & 0 & 0.5 & 1 & 0.5 & 1 & 1 & 0 & 0 & 4 \\
\hline 1 & 0.5 & 0.5 & 1 & 0.5 & 1 & 0 & 0.5 & 1 & 0.5 & 1 & 1 & 0 & 0.5 & 5 \\
\hline
\end{tabular}


Table 4. cont.

\begin{tabular}{|c|c|c|c|c|c|c|c|c|c|c|c|c|c|c|}
\hline \multicolumn{10}{|c|}{ Characteristic features of the area } & \multirow{2}{*}{$\begin{array}{c}\text { Sector } \\
\text { No. }\end{array}$} \\
\hline T1 & T2 & T3 & T4 & T5 & T6 & T7 & T8 & T9 & T10 & T11 & T12 & T13 & T14 & (1 \\
\hline 1 & 0.5 & 0.5 & 1 & 0.5 & 1 & 0 & 1 & 1 & 0.5 & 1 & 0 & 0 & 0.5 & 6 \\
\hline 0.5 & 0.5 & 0.5 & 0.5 & 1 & 0.5 & 0 & 1 & 1 & 0.5 & 1 & 0 & 0 & 0.5 & 7 \\
\hline 1 & 0.5 & 0.5 & 0.5 & 1 & 0.5 & 0 & 1 & 1 & 0.5 & 0.5 & 0.5 & 0 & 0 & 8 \\
\hline 1 & 0.5 & 0.5 & 0.5 & 0.5 & 0 & 0 & 0 & 0 & 0 & 0 & 0 & 0 & 0 & 9 \\
\hline 0.5 & 0.5 & 0.5 & 1 & 0.5 & 1 & 0 & 0.5 & 0.5 & 0.5 & 0.5 & 0 & 0 & 0.5 & 10 \\
\hline
\end{tabular}

Source: Authors' study

Table 5. Fragment of the matrix of values assigned to features in the VT4 area for the first 10 measurement sectors

\begin{tabular}{|c|c|c|c|c|c|c|c|c|c|c|c|c|c|c|}
\hline \multicolumn{10}{|c|}{ Characteristic features of the area } & \multirow{2}{*}{$\begin{array}{c}\text { Sector } \\
\text { No. }\end{array}$} \\
\hline T1 & T2 & T3 & T4 & T5 & T6 & T7 & T8 & T9 & T10 & T11 & T12 & T13 & T14 & ( \\
\hline 0.5 & 0.5 & 1 & 0.5 & 1 & 0 & 0 & 0.5 & 0.5 & 0 & 0 & 0.5 & 0 & 1 \\
\hline 0.5 & 0.5 & 0.5 & 1 & 0.5 & 1 & 0 & 0 & 0.5 & 0.5 & 0 & 0 & 0.5 & 0 & 2 \\
\hline 0.5 & 0.5 & 0.5 & 1 & 1 & 0.5 & 0 & 0.5 & 0 & 0.5 & 0 & 0 & 0.5 & 0 & 3 \\
\hline 0.5 & 0.5 & 0.5 & 0.5 & 1 & 0.5 & 0 & 0.5 & 0 & 0.5 & 0 & 0 & 0 & 0 & 4 \\
\hline 0.5 & 0.5 & 0.5 & 1 & 1 & 0.5 & 0 & 0.5 & 0.5 & 0.5 & 0 & 0 & 0.5 & 0 & 5 \\
\hline 1 & 0.5 & 0.5 & 1 & 1 & 0.5 & 0 & 0.5 & 0.5 & 0.5 & 0 & 0 & 0.5 & 0.5 & 6 \\
\hline 1 & 0.5 & 0.5 & 0 & 1 & 0.5 & 0 & 0.5 & 0.5 & 0.5 & 0 & 0 & 0 & 0.5 & 7 \\
\hline 1 & 0.5 & 0.5 & 0.5 & 1 & 0.5 & 0 & 0.5 & 0.5 & 0.5 & 0 & 0 & 0 & 0.5 & 8 \\
\hline 0.5 & 0.5 & 0.5 & 1 & 1 & 0.5 & 0 & 0.5 & 0 & 0 & 0 & 0 & 0.5 & 0.5 & 9 \\
\hline 1 & 0.5 & 0.5 & 1 & 1 & 0.5 & 0 & 0.5 & 0 & 0 & 0 & 0 & 0.5 & 0.5 & 10 \\
\hline
\end{tabular}

Source: Authors's study

The sectors presented in the form of the above matrices, systematised and valued, allow for the calculation of the general score for each sector, using the scalar product:

where:

$$
V T_{n} W_{j k}=\sum_{i=1}^{c} V T_{n i} \cdot W_{i j k}
$$

$V T_{n}-n$-th row of matrix $V T$,

$W_{j k}-j$-th column of $k$-th layer of weight matrix $W$. 
The interpretation of the above formula indicates that the general score is a value that depends on the characteristic features of the given area, the determined weights of conditions and the functional designation.

Continuous economic and social development forces the control of the performed assessment of features, their weights, and care for updating the database, according to the current status at a given moment. In order to emphasize the significance of the conditions (determinants) included in the study, an appropriate vector of conditions' weights should be adopted:

$$
W W U=\left(w w u_{1}, w w u_{2}, w w u_{3}, w w u_{4}, w w u_{5}\right) .
$$

In doing that, we need to assume that the individual coordinates meet the following condition:

$$
\text { for each } i=1,2,3,4,5 \leq w w u_{i} \leq 1, \sum_{i=1}^{m} w w u_{i}=1
$$

The general score for sector $V G_{c, s}$ for the functional designation $c$ and sector $s$ is calculated from the following formula:

$$
V G_{c, s}=\sum_{i=1}^{m} w w u_{i} \cdot v_{i}
$$

where $V_{i}$ - value of the functional designation assessment in terms of the $i$-th condition.

For the conditions (determinants) adopted previously, the following weights have been determined.

Table 6. Valorisation of selected sets of conditions

\begin{tabular}{|c|l|c|}
\hline Symbol & \multicolumn{1}{|c|}{ Name } & Weight \\
\hline ww1 & Environmental & $5 / 16$ \\
\hline ww2 & Economic & $4 / 16$ \\
\hline ww3 & Social & $3 / 16$ \\
\hline ww4 & Legal & $2 / 16$ \\
\hline ww5 & Aesthetic & $2 / 16$ \\
\hline
\end{tabular}

Source: Authors'study

According to the above, the general score for the assessment takes the following format:

$$
\begin{gathered}
{\left[\left(V T_{k 1}+V T_{k 2}+V T_{k 3}+V T_{k 4}+V T_{k 5}\right) \cdot 17+\left(V T_{k 10}+V T_{k 13}+V T_{k 14}\right) \cdot 5\right] \cdot 5 / 16+} \\
+\left[\left(V T_{k 4}+V T_{k 6}+V T_{k 7}+V T_{k 8}\right) \cdot 19+\left(V T_{k 11}+V T_{k 12}\right) \cdot 10+\left(V T_{k 13}+V T_{k 14}\right) \cdot 2\right] \cdot 4 / 16+ \\
+\left[\left(V T_{k 8} \cdot 29+V T_{k 9} \cdot 31+V T_{k 10} \cdot 28+\left(V T_{k 13}+V T_{k 14}\right) \cdot 6\right] \cdot 3 / 16+\right. \\
+\left[\left(V T_{k 11}+V T_{k 12}\right) \cdot 48+V T_{k 6} \cdot 2+\left(V T_{k 13}+V T_{k 14}\right) \cdot 1\right] \cdot 2 / 16+ \\
+\left[\left(V T_{k 15}+V T_{k 14}\right) \cdot 40+\left(V T_{k 8}+V T_{k 10}\right) \cdot 10\right] \cdot 2 / 16
\end{gathered}
$$


The last stage of the calculation is based on the computation of the matrix $O C_{k}$, which illustrates the evaluation of the functional designations with respect to the chosen condition (determinant) $k$. The matrix $O C_{k}$ is the result of left-sided multiplication of the $k$-th layer of the matrix $W$ by the matrix $V T$. The implementation of this operation for all interpreted conditions leads to successively obtaining matrices $O C_{1}$, $O C_{2}, O C_{3}, \ldots, O C_{k}$. When analysing any chosen sector $s$ and one of the three assumed functional designations, we select elements $(s, c)$ from the matrix $O C_{k}$, we get a series of values of the sector $s$ evaluation for the functional designation of $c$, where the individual elements correspond to five conditions.

Conducting the computations described above for all sectors and the adopted conditions (determinants), broken down into specific functional designations, constitutes a multi-valued assessment presented as a sequence of numbers:

$$
\left(v_{1}, v_{2}, v_{3}, v_{4}, v_{5}, c, s\right)
$$

where:

$v_{n}$ - values of functional designation assessments, taking into account the conditions (determinants) adopted for the analysis:

$v_{1}$ - ecological (environmental)

$v_{2}-$ economic

$v_{3}-$ social

$v_{4}-$ legal

$v_{5}$ - aesthetic

$s$ - is the number of the evaluated sector,

$c$ - is the functional designation.

Further analysis consists in choosing the sectors with the highest score relative to the determinant $k$ and the designation $c$ forming the set of $\operatorname{Max}(c, k)$. Any conjunction of several sets $\operatorname{Max}(c, k)$ that is non-blank is a common field, which can be used in the same way, but when the same sets or similarly values sets are obtained for different functional designations, they indicate the sought conflict area that requires the development of a local plan.

When choosing the best sectors for a chosen purpose (functional designation), for example the best field for tourism development $(c=1)$ as well as construction $(c=2)$, we can be guided by all the conditions, or select only those of particular interest to us. If we are interested in choosing conflict areas for specific reasons, which are - for instance - economic $(k=2)$ or social $(k=3)$ in nature, we choose sectors that satisfy the following dependence:

$$
\operatorname{Max}(1,2) \cap \operatorname{Max}(2,2) \cap \operatorname{Max}(1,3) \cap \operatorname{Max}(2,3)
$$

The values included in this set represent the sectors, for which it is necessary to draw up local spatial development plans. 
The necessary condition under this method was to divide the surveyed area into 250 sectors, each of which was assessed in the course of the analysis, in terms of its suitability to fulfil the intended designated function. As a result, the suitability of the sectors for performing one of the functions is given as a set of numbers, in which the highest score relative to a given condition is 100 , and the lowest is 0 . Presentation of the results in the form of a matrix allows for a multidirectional analysis of each sector. This makes it possible to interpret the obtained values, while taking into account the data in the columns of the matrix (occurrence and distribution of the phenomenon) or arrangement of positions in the rows (which exposes the relationship between the features of the object, and their designated functions). The comparison of individual columns indicates the existence of spatial covariance, while the analysis of the rows in the matrix represents the spatial diversity of the set of the studied characteristic features.

Based on the results of the research, it can be observed that the ecological (environmental) and aesthetic conditions have the greatest impact on the development of tourism and leisure. In this case, this indicates the importance of the occurrence of such elements as, for example: forms of the terrain, geological structure, soil viability, occurrence of forests and other vegetation, surface waters, the attractiveness of the area and the spatial harmony or lack thereof. Each of these elements during the evaluation of individual sectors was interpreted individually in relation to a specific function.

In the case of single-family and multi-family housing function as well as agricultural function, the first three conditions were rated the highest: ecological $(w w 1)$, economic $(w w 2)$, and social ( $w w 3)$. They take into account such elements as for instance aspirations and expectations of residents, the condition and cultural value of the environment, as well as legal stipulations.

In order to perform a comprehensive assessment of individual sectors, all five conditions $(w w 1-w w 5)$ and all three functional designations as shown in table 5 should be taken into account.

In the comprehensive assessment of individual sectors, a condition is assumed that a given area is capable of performing a specific function or a set of functions, if at least two conditions (determinants) are taken into account. Five analysed conditions (determinants) lead to creating a series of different combinations that indicate conflict areas (sectors). Ten possible combinations (pairs of determinants) are shown graphically below. Depending on the chosen pairs of conditions, a variety of results can be observed in terms of the functional designations adopted in the study.

Below we find a graphical depiction (Figs 4-6) of areas suitable for the development of tourism function ("T"), construction function ("B"), agricultural function ("R"), industrial function ("P") and conflict areas: "T + B", “T + R", "B + R", "B + R", " $\mathrm{R}+\mathrm{P}$ ", taking into account selected pairs of determinants: 1 - ecological-economic, 2 - ecological-social, 3 - ecological-legal, 4 - ecological-aesthetic, 5 - economic-social, 6 - economic-legal, 7 - economic-aesthetic, 8 - social-legal, 9 - social-aesthetic, and 10 - legal-aesthetic. 

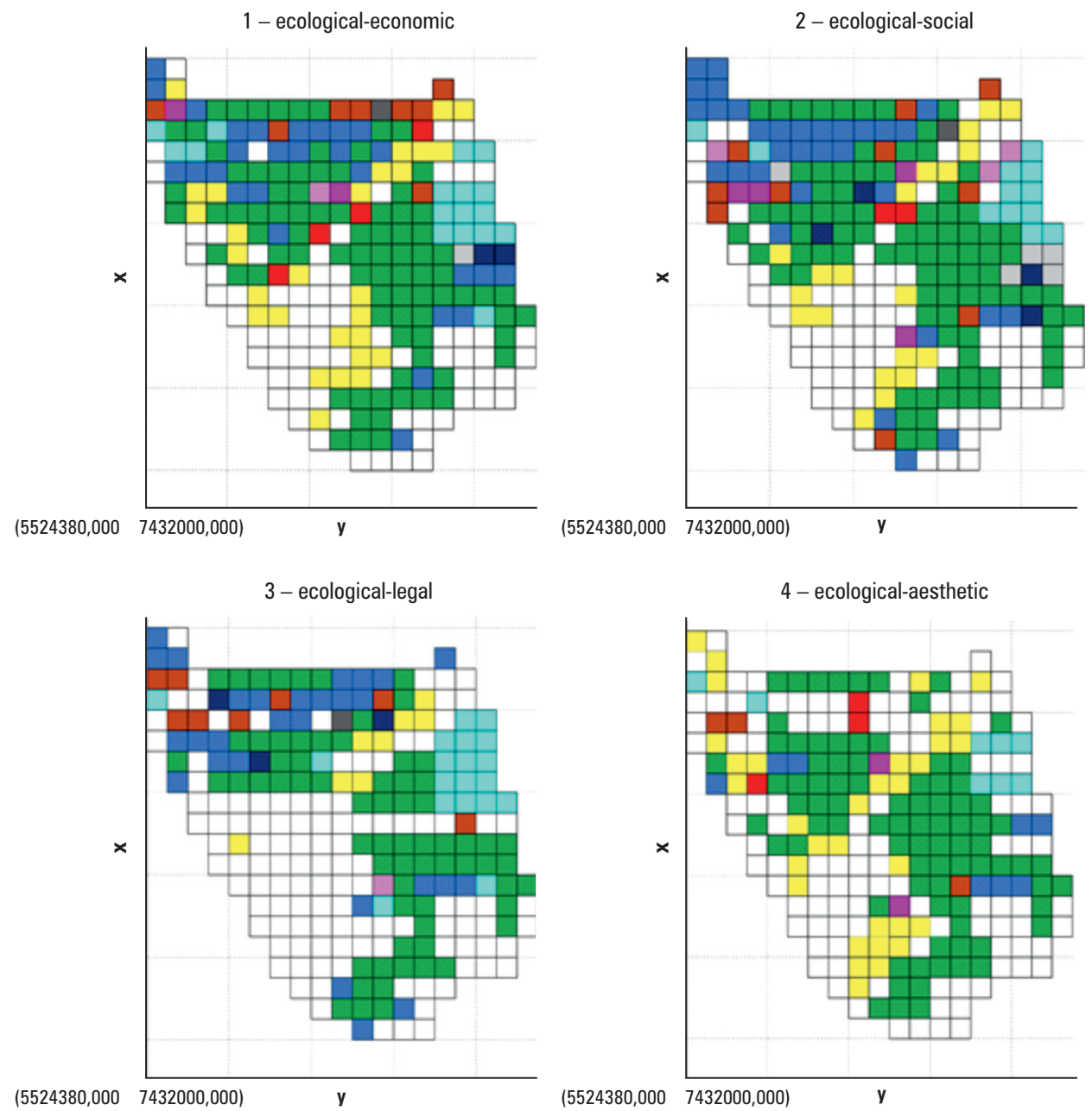

Source: Authors' study

Fig. 4. Presentation of the pairs of determinants (conditions) 

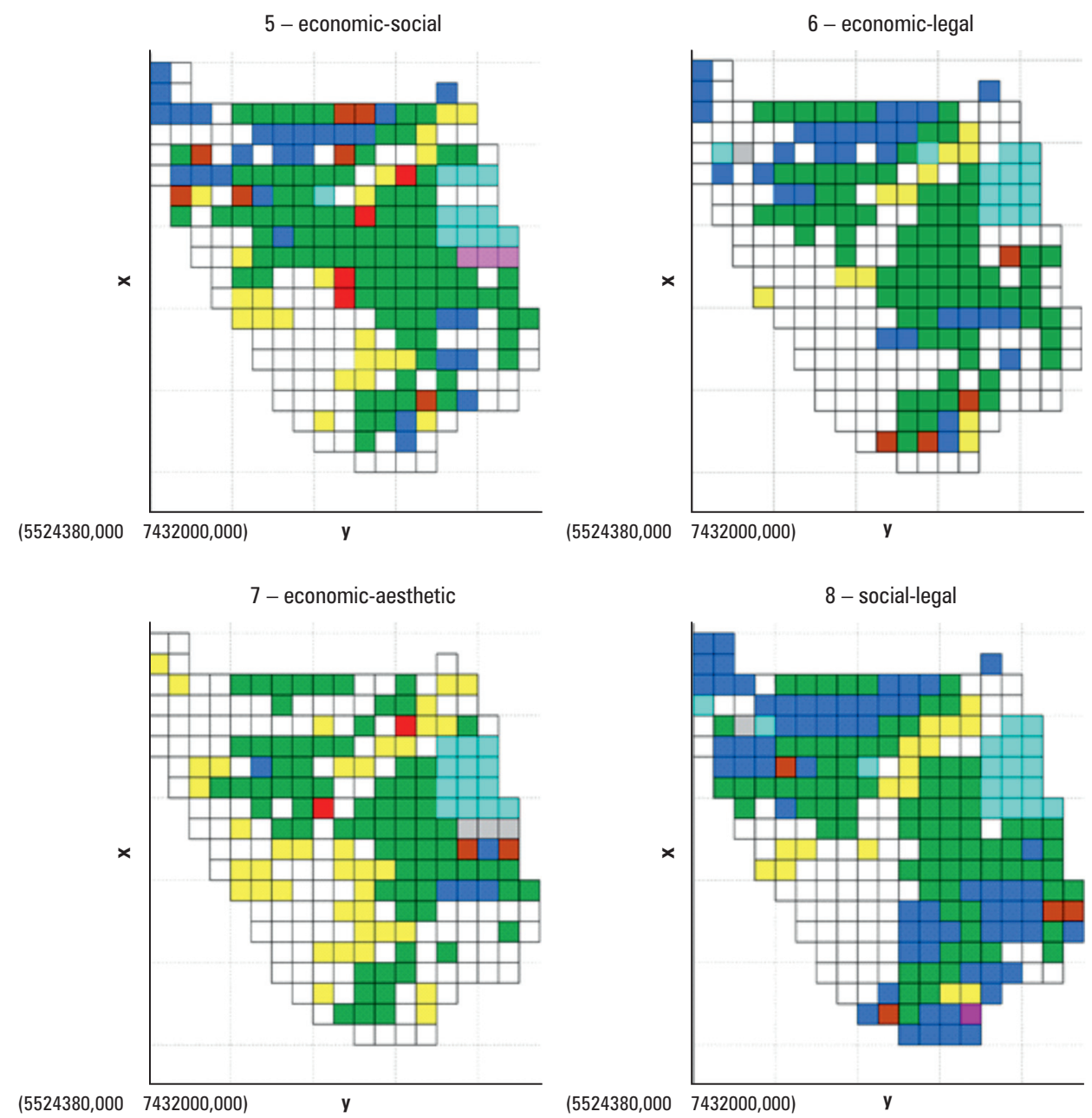

Source: Author's study

Fig. 5. Presentation of the pairs of determinants (conditions) 

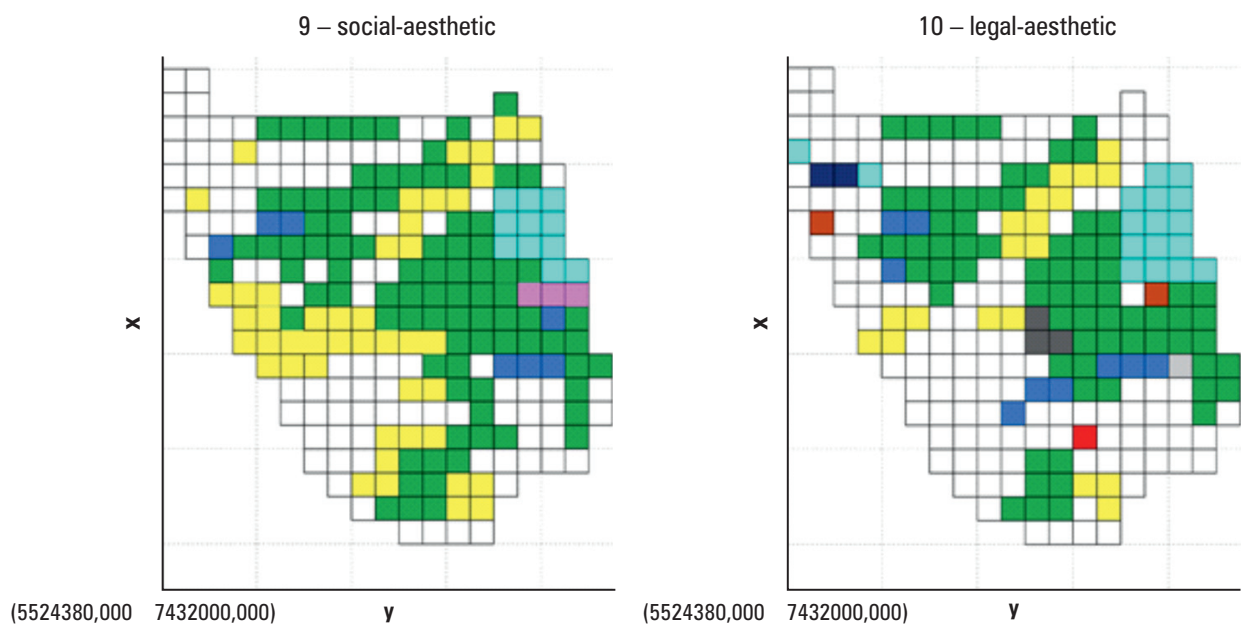

Source: Authors' study

Fig. 6. Presentation of the pairs of determinants (conditions)

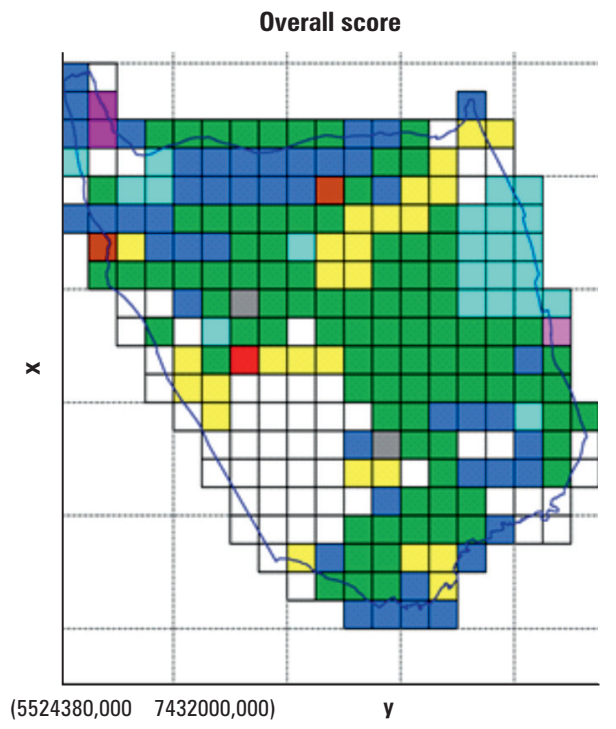

Key

$\square$ Agriculture

$\square$ One-family and multi-family housing

$\square$ Tourism and leisure

$\square$ Industry and services

\section{Conflict zones}

$\square$ Agriculture/One-family and multi-family housing

Agriculture/Tourism and leisure

$\square$ One-family and multi-family housing/Tourism and leisure

One-family and multi-family housing/Industry and services

Industry and services/Agriculture

- Administrative boundaries of Dobczyce town

Source: Authors's study

Fig. 7. Graphical presentation of the overall score

When interpreting the first diagram, one observes 20 sectors belonging to the set of conflict areas. This result is due to the contradictory nature of the two juxtaposed determinants, in this case ecological (environmental) and economic. Bajerowski [2003] 
compares this juxtaposition to the "victim" and "predator" model, i.e. that the economic benefits in a given area inevitably lead to ecological losses. Therefore, this indicates to the capacities of using the given area along with its limitations. Such area can be used only up to the break-even point (reaching profitability), or the maximum burden on the existing flora and fauna.

The second diagram indicating a large number of conflict sectors is diagram 9, presenting social and aesthetic conditions. It becomes obvious that the inhabitants' expectations and needs regarding the possibility of using the land do not go hand in hand with the existing state and the capacity of the environment. Space should constitute a harmonious whole on these two levels.

Focusing on the interpretation of the three objectives, it is evident that the areas devoted to the development of tourism and leisure are located along the Raba river (the central part of the analysed area, stretching from the south-west to the north-east part of the city). It is an attractive area, primarily in terms of its natural qualities. Individual sectors (for instance, 140-142) indicate the most interesting and valuable heritage objects, being a kind of showcase of the city of Dobczyce.

Such placement of areas suitable for fulfilling the tourism and leisure function is suggested by the following determinants: socio-aesthetic, ecological-aesthetic as well as legal-aesthetic. For the other determinants, locations of suitable sectors are more chaotic and dispersed.

Above all, however, the modified multi-valued method applied herein indicates the large potential of the city to develop one-family and multi-family housing. All the presented diagrams show a high degree of compliance with the location of this type of investment. The designated sectors mostly present already built-up areas as well as those located along major roads.

Taking into account economic and aesthetic determinants (Diagram 7) as well as social and aesthetic determinants (Diagram 9), there are several sectors that are suitable for the development of both tourism and leisure as well as for construction development. This points to the fact that the features taken into account for economic, social and aesthetic considerations alike affect in a very similar way the development of both analysed functions. The situation is similar in the case of areas that are suitable for both tourism and agriculture. The greatest number of conflict sectors can be seen in diagrams 1,2 and 5 .

Areas favourable for the development of agricultural production function, depending on the conditions, are scattered throughout the analysed area. The largest number of relevant sectors is located in the northern and southern parts of the city. These areas are either mainly used for agriculture, or they are wasteland that was once used as arable land or meadows. The largest number of sectors suitable for this purpose is shown in Diagram 8, describing social and legal conditions. The high importance of these conditions is strongly related to the economic nature of the town. The local community have been making their living in agriculture for many years - hence it is natural that these sectors score highly in this respect, due to local habits and stabilized legal issues. 
In addition to the aforementioned conflict areas, one can also observe those that indicate the same suitability of a given area for the functions of agriculture and of construction. Diagrams 1, 2, 6 and 9 indicate the greatest number of such conflict zones.

When creating a comprehensive assessment of the studied area, all previously determined conditions should be taken into account, including their importance - that is their weights, previously determined for the purpose of evaluation. Graphical interpretation of the overall score is presented in Figure 7. This illustrates the overall assessment of areas whose score is higher than 50 - for which it is necessary to draw up a local spatial development plan.

\section{Conclusions}

Collating the final list of the results obtained with the existing spatial development plan for the city led to the observation that the vast majority of areas in the plan are intended for performing similar functions as those obtained as a result of the modified multivalent method. Small differences between the two methods of determining designated functions of the areas occur when the local plan indicates the use of areas for other functions, being outside the scope of our study. However, it is the advantage of the method applied and presented in this paper, that it allows for extending the number of analysed functions, and facilitates adopting any number of characteristic features, in order to supplement, correct or narrow them down, and thus eliminate the emergence of conflict situations. One of the additional advantages of the modified method, indicating its flexibility, is the ability to assess areas due to the arbitrarily chosen list of conditions (determinants). Another implication of the modified method is the complexity of propositions and solutions that enable taking full advantage of the features of the analysed environment, and provide an excellent basis for any planning activities in any chosen area.

In the face of the diversity of results obtained, it is also appropriate to state that all transformations in the functional structure of a city require an initiative and cooperation on the part of local authorities, town planners, investors and the local community in the pursuit of the best possible use of space. The full scope of actions undertaken by all these parties and entities produces the so-called phenomenon of synergy, towards a harmonious development of urban space [Antosiewicz 2008].

\section{References}

Antosiewicz T. 2008. Kształtowanie przestrzeni publicznej w związku z intensywnym rozwojem współczesnych miast - zarys problematyki. Kultura i Polityka: Zeszyty Naukowe Wyższej Szkoły Europejskiej im. ks. Józefa Tischnera w Krakowie, 4, 43.

Bajerowski T. 1995. Macierz optymalnego sposobu użytkowania ziemi jako instrument przyszłego zagospodarowania obszarów wiejskich. Geodezja i Kartografia, PWN, XLIV, 2-3, 271-279.

Bajerowski T. 1996. Metodyka wyboru optymalnego użytkowania ziemi na obszarach wiejskich. Wydawnictwo Akademii Rolniczo-Technicznej, Olsztyn. 
Koreleski K. 1993. Przyrodnicze podstawy użytkowania rolniczej przestrzeni produkcyjnej. Wyd. AR w Krakowie, wyd. III.

Kurek W., Mika M. 2007. Turystyka jako przedmiot badań naukowych. [W:] Kurek W. (red.), Turystyka. Wyd. Naukowe PWN, Warszawa, 11-49.

Lijewski T., Mikułowski B., Wyrzykowski J. 2002. Geografia turystyczna Polski. PWE, Warszawa.

Litwin U., Bacior S., Piech I. 2009. Metodyka oceny i waloryzacji krajobrazu. Polska Akademia Nauk, Oddział w Krakowie, 3, 14-25.

Litwin U., Bacior S., Piech I. 2010. Nowoczesne metody wartościowania krajobrazu. Polska Akademia Nauk, Oddział w Krakowie, 3, 147-155.

Litwin U., Piech I. 2010. Metoda wielowartościowa jako podstawa wyboru obszarów wymagających sporządzania planów miejscowych na przykładzie gminy Trzebownisko. Polska Akademia Nauk, Oddział w Krakowie, 3, 29-40.

Matczak A. 1989. Problemy badania funkcji turystycznej miast Polski. Acta Universitatis Lodziensis, Turyzm, 5, 29.

Misiak K. 2017. Analiza funkcjonalno-przestrzenna miasta Dobczyce z wykorzystaniem metody wielowartościowej.

Parysek J. 2007. Wprowadzenie do gospodarki przestrzennej: wybrane aspekty praktyczne. Wydawnictwo Naukowe UAM, Poznań, 66-67.

Pogodziński Z. 1975. Planowanie przestrzenne terenów wiejskich. PWN, Warszawa.

Raszeja E., Mikulski D. 2016. Zintegrowana ocena społecznej wartości krajobrazu na obszarze ziemi średzkiej. Przestrzeń i Forma, 26, 145-162.

Stola W. 1993. Struktura przestrzenna i klasyfikacja funkcjonalna obszarów wiejskich Polski. Wydawnictwo Polskiej Akademii Nauki, Warszawa.

Szczurowska M., Podawca K., Gworek B. 2006. Struktura funkcjonalna obszarów wiejskich. Ochrona środowiska i Zasobów Naturalnych, 29.

Uchwała Nr XXVI/164/16 z dnia 7 września 2016 r. - cz. 1. Tekst planu. Dziennik Urzędowy Województwa Małopolskiego.

Uchwała Nr XXVI/164/16 z dnia 7 września 2016 r. - cz. 2. Rysunek planu. Dziennik Urzędowy Województwa Małopolskiego.

Uchwała Nr XXVI/164/16 z dnia 7 września 2016 r. - cz. 3 - zał. nr 2 i 3 - Dziennik Urzędowy Województwa Małopolskiego.

Uchwała Nr XV/109/2011 Rady Miejskiej w Dobczycach z dnia 26 października 2011 r. w sprawie zmiany Studium uwarunkowań i kierunków zagospodarowania przestrzennego Miasta i Gminy Dobczyce, t. 1. Uwarunkowania.

Wierzchowski W. 1996. Metoda wielowartościowa jako podstawa wyboru obszarów wymagających sporządzania planów miejscowych. Wydawnictwo ART, Olsztyn.

Prof. dr hab. inż. Urszula Litwin

Uniwersytet Rolniczy w Krakowie

Katedra Geodezji Rolnej, Katastru i Fotogrametrii

ul. Balicka 253a, 30-198 Kraków

e-mail: urszula.litwin@urk.edu.pl

ORCID: https://orcid.org/0000-0002-9457-3816

mgr inż. Karolina Misiak

Doktorantka WIŚiG

e-mail: karmis@poczta.onet.pl 